\title{
NEW TAXA AND NEW RECORDS FROM THE TASMANIAN LICHEN FLORA
}

\author{
by John A. Elix and Gintaras Kantvilas
}

(with three plates)

\begin{abstract}
Erix, J.A. \& Kanivilas, G., 1995 (30:vi): New taxa and new records from the Tasmanian lichen flora. Pap. Proc. R. Soc. Tasm. 129: 63-68. https://doi.org/10.26749/rstpp.129.63 ISSN 0080--4703. Department of Chemistry, Australian National University, Canberra, ACT, Australia 0200 QAE); Tasmanian Herbarium, GPO Box 252C, Hobart, Tasmania, Australia 7001 (GK).
\end{abstract}

Three new lichens from Tasmania, Cladonia sulcata var. depleta Elix \& Kantvilas, Parmelia tarkinensis Elix \& Kantvilas and Xanthoparmelia jarmaniae Elix \& Kantvilas are described. Eleven additional taxa are reported from Tasmania for the first time, and notes on their distinguishing features, distribution and ecology are provided.

Key Words: lichens, flora, Cladonia, Parmelia, Xanthoparmelia, Tasmania.

\section{INTRODUCTION}

Since the publication of the latest checklist of Tasmanian lichens (Kantvilas 1994), further collecting and floristic, ecological and taxonomic research on the flora has continued, resulting in a number of additions to the Tasmanian census. In the present paper we describe a new corticolous species in the genus Parmelia, a new saxicolous species of Xanthoparmelia and a new variety of Cladonia, and report 11 taxa from Tasmania for the first time.

\section{METHODS}

The study is based primarily on collections in the Tasmanian Herbarium (HO) and the Australian National Herbarium (CANB). For all taxa, determinations are based on comparisons with type and/or reliably identified reference material. Anatomical and chemical investigations follow standard methods.

\section{TAXONOMY}

Buellia badia (Fr.) Massal., Memor. Lichenogr. 1853:124 (1853) - Lecidea badia Fr., Syst. Orb. Veget. 1: 287 (1825)

Buellia badia is characterised by a dark-brown, areolatecrustose to small-squamulose thallus, black, lecideine apothecia, a hymenium lacking oil droplets, and brown, 1-septate ascospores, $10-15 \times 7-8.5 \mu \mathrm{m}$, which lack lateral thickenings (for further descriptive data, Scheidegger 1993; for an illustration, Wirth 1987).

This species is widespread in the Northern Hemisphere and is also known from New Zealand. It is typically lichenicolous on a wide range of foliose and crustose lichen genera (Scheidegger 1993). The Tasmanian record is from the thallus of Tephromela atra on sandstone outcrops in dry sclerophyll forest.

Specimen examined

C. $3 \mathrm{~km}$ southeast of Broadmarsh, $42^{\circ} 41^{\prime} \mathrm{S}, 1^{\circ} 47^{\circ} 09^{\prime} \mathrm{E}, 60$ m, 11 December 1993, G. Kantvilas 157/93 \& J.A. Elix (HO).
Candelariella aurella (Hoffm.) Zahlbr.,

Catal. Lich. Univ. 5: 790 (1928) - Verrucaria aurella Hoffm., Deutsch. Fl: 197 (1796)

Candelariella aurella is characterised by a yellow to greenishgrey, granular to evanescent thallus, and apothecia with eight-spored asci (for descriptions, Filson 1992, Purvis et al. 1992, Galloway 1985). The species is cosmopolitan and occurs on limestone or, more commonly, on man-made substrates such as concrete or asbestos. Although currently known in Tasmania from only a single specimen from mortar, and in mainland Australia from a sole collection from South Australia (Filson 1992), the species is likely to be more widespread in urban areas.

Two other species of Candelariella occur in Tasmania: $C$. xanthostigmoides grows on bark and has a granular to sorediate thallus and eight-spored asci, whilst $C$. vitellina (see below) occurs on siliceous rocks and has polyspored asci.

Specimen examined

Hobart, 9 Lallaby Road, Moonah, 1965, G.C. Bratt 1919 (HO).

\footnotetext{
Candelariella vitellina (Hoffm.) Müll. Arg., Bull. Herb.

Boissier 2, App. 1: 47(1894) - Patellaria vitellina Hoffm., Descr. Pl. Cl. Crypt. 2: 5 (1794)
}

Candelariella vitellina is a widespread cosmopolitan lichen, recognised by its polyspored asci, usually containing 12-32 ascospores, and by its saxicolous habitat. The species is morphologically very variable, with greenish-yellow to golden-yellow areolae, which may be either dispersed or clustered into thick pulvinate clumps (for full description, Galloway 1985). Although specimens from alpine and subalpine areas tend to have a thicker, more prominent thallus (Filson 1992) as well as somewhat larger apothecia (up to c. $0.8 \mathrm{~mm}$ diam. in comparison to $<0.5 \mathrm{~mm}$ in the lowlands), there appears to be no consistent correlation between thallus morphology and ecology. Nor are the morphological differences supported by anatomical differences. 
In Tasmania, C. vitellina is widespread in central and eastern areas from lowland to alpine altitudes. It grows on exposed sandstone and dolerite outcrops in heathland and open sclerophyll woodland, frequently in bird-perching sites. In mainland Australia, this species is common on rocks in South Australia, Victoria, New South Wales and the Australian Capital Territory.

Selected specimens examined (total $=10$ )

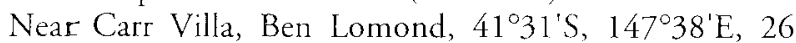
Janu ary 1969, G.C. Bratt 69/81 (HO, AD); Central Plateau, Lake Augusta Dam, $41^{\circ} 51^{\prime} \mathrm{S}, 146^{\circ} 35^{\prime} \mathrm{E}, 1140 \mathrm{~m}, 7$ December 1993, J.A. Elix 40064 \& G. Kantvilas (CANB), G. Kantvilas $177 / 93$ \& J.A. Elix (HO); Mt Wellington, 42054'S, $147^{\circ} 14^{\prime} \mathrm{E}, 1260 \mathrm{~m}, 11$ February 1984, G. Kantvilas \& P.W. James 300/84 (HO, BM); Maria Island near Darlington, $42^{\circ} 35^{\prime} \mathrm{S}, 148^{\circ} 08^{\prime} \mathrm{E}, 60 \mathrm{~m}, 12$ March 1981, G. Kantvilas $173 / 81$ (HO, BM); Hunting Ground at northwestern end of Middle Tier, $42^{\circ} 32^{\prime} \mathrm{S}, 147^{\circ} 08^{\prime} \mathrm{E}, 180 \mathrm{~m}, 11$ December 1993, G. Kantvilas 169/93 \& J.A. Elix (HO).

Cladonia sulcata var. depleta

Elix \& Kantvilas, var. nov. (PI. 1)

Haec varietas a varietate typic a absentia depsidonicarum differt.

\section{Type}

Arthur-Pieman Protected Area, $32 \mathrm{~km}$ NNE of Savage River, along the Pipeline Road, $41^{\circ} 16^{\prime} \mathrm{S}, 145^{\circ} 19^{\prime} \mathrm{E}, 480 \mathrm{~m}$ elevation, on soil bank along margin of mixed rainforest, 8 December 1993, J. A. Elix 40118 \& G. Kantvilas (HO holotype; CANB - isotype; Lichenes Australasici Exsiccati - isotypes).

Primary squamules persistent or evanescent, $2-5 \mathrm{~mm}$ long, 1-2 $\mathrm{mm}$ wide, esorediate. Podetia growing from primary squamules, $1-4 \mathrm{~cm}$ tall, not scyphose, simple at base, branching above, each branch longitudinally grooved and becoming split, with open axils, rarely with scattered squamules along the podetia, esorediate, greyish white. Cortex continuous at base, becoming finely warted and areolate. Apothecia on the tips of podetia, $0.4-0.8 \mathrm{~mm}$ diameter, convex, pale to dark brown; ascospores 10-15X 3-4 $\mu \mathrm{m}$. Pycnidia terminal on podetia, black; conidia filiform, 5.5-7.0 $\times 0.5-1 \mu \mathrm{m}$.

\section{Chemistry}

$\mathrm{K}+$ yellow, $\mathrm{C}-, \mathrm{KC}-, \mathrm{P}+$ yellow; containing atranorin (major), bourgeanic acid (major).

This new variety is morphologically indistinguishable from the other three varieties of Cladonia sulcata (Archer 1992), but is chemically unique, in that it lacks the depsidones typical of the other three taxa. Thus the major constituents are psoromic acid in C. sulcata var. sulcata, norstictic acid in C. sulcata var. striata, and stictic acid in C. sulcata var. wilsonii (all in addition to atranorin and bourgeanic acid) while $C$. sulcata var. depleta lacks any additional depsidones. At present this new variety is only known from the type locality where it is particularly common and luxuriant on disturbed earth at the edge of cool temperate rainforest.

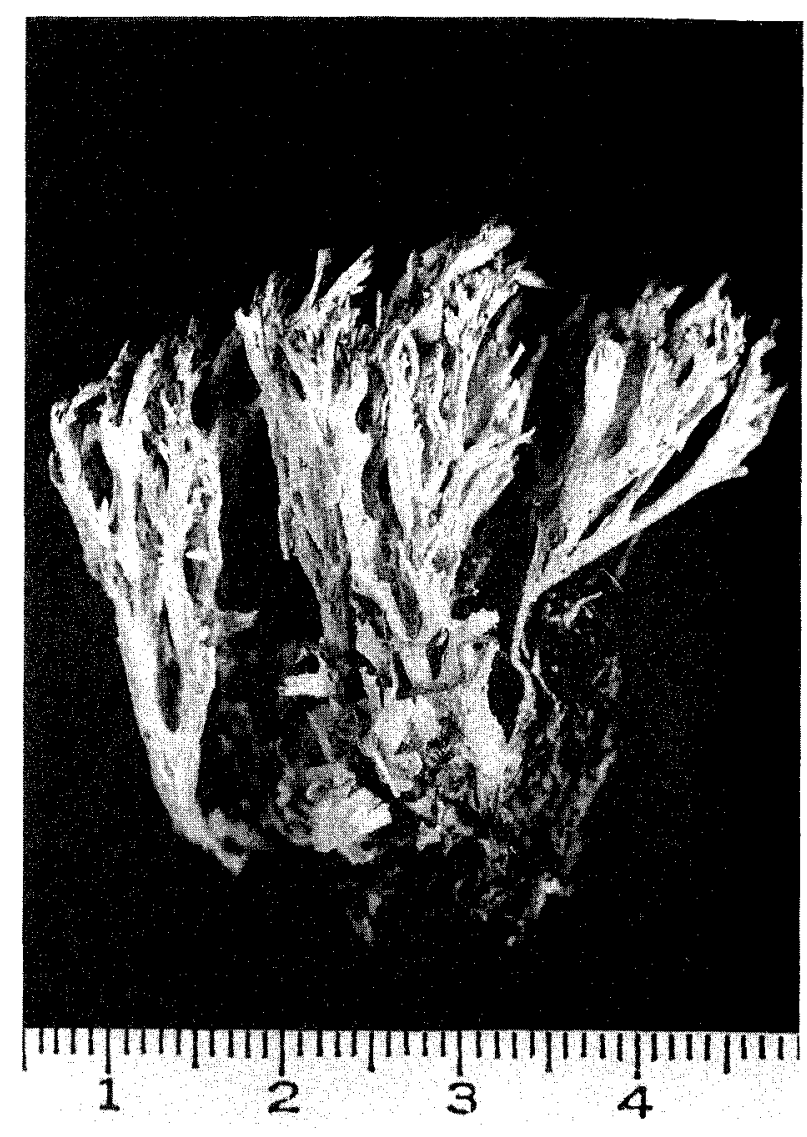

\section{PLATE I}

Cladonia sulcata var. depleta (isotype)

Hypogymnia australica Elix in J.A. Elix \& G.A. Jenkins, Mycotaxon 35: 469 (1989)

Hypogymnia australica is characterised by the linear-elongate, di- or trichotomously branched, narrow (1-3 mm wide), hollow lobes which become subcontiguous in the centre of the thallus, the P-medulla, blackened adjacent to the lobe cavity, the absence of perforations in the lower cortex, and the evenly distributed apothecia with swollen, urceolate bases (for description, discussion and illustration, Elix \& Jenkins 1989). This endemic Australian species is quite common east of the Great Dividing Range in New South Wales but is either rare or has been previously overlooked in Tasmania. The single record is from a tree trunk in a Eucalyptus forest with a thick understorey of Olearia and Leptospermum.

Specimen examined

Standard Hill, $30 \mathrm{~km}$ WSW of Deloraine, $41^{\circ} 33^{\prime} \mathrm{S}$, $146^{\circ} 18^{\prime} \mathrm{E}, 440 \mathrm{~m}, 28$ November 1988, J.A. Curnow 2196 (CANB, HO).

Hypotrachyna immaculata (Kurok.) Hale, Smithsonian Contrib. Bot. 25: 41 (1975)

- Parmelia immaculata Kurok. in Hale \& Kurokawa, Contrib. U.S. Nat. Herb. 36:178 (1964)

This species is distinguished by the sublinear, subdichotomously branched lobes with truncate apices, the prominent capitate soralia, the dense, richly branched dichotomous rhizines, the UV-upper cortex (lacking lichexanthone) and 
the presence of the lividic acid complex in the medulla (for a full description, Elix 1994a).

Hypotrachyna immaculata occurs in two sympatric chemical races: one in which lividic acid is preponderant, the other in which colensoic acid and 4-O-merhylphysodic acids are the major substances.

This temperate-tropical species is common on rocks and bark in most habitats in eastern Australia (Queensland, New South Wales, Australian Capital Territory and Victoria) and is also known from South America and Africa. The single Tasmanian collection is from granite outcrops in open coastal woodland-heathland.

Specimen examined

Tasmania-Mt Amos, $42^{\circ} 09^{\prime} \mathrm{S}, 148^{\circ} 18^{\prime} \mathrm{E}, 480 \mathrm{~m}, 28 \mathrm{July}$ 1991, G. Kantvilas 285/91 (HO).

\section{Lecidella elaeochroma (Ach.) M. Choisy, Bull. Mens. Soc. Linn. Lyon 19:19 (1950) - Lecidea parasema var. elaeochroma Ach., Meth. Lich.: 36 (1803)}

This species was previously listed for Tasmania on the basis of collections from cool temperate rainforest, wet scrub and buttongrass moorland (Kantvilas 1988, Kantvilas \& Jarman 1988). However, that material was subsequently recognised as belonging to a separate, undescribed taxon (Kantvilas 1994). Now Lecidella elaeochroma sens.str. is confirmed for Tasmania, where it grows on the twigs of Hymenanthera prostrata in alpine heathland, a habitat virtually identical to where it grows in mainland Australia (Hertel 1985). This Tasmanian material accords very closely to specimens from the Northern Hemisphere. It is characterised by the smooth to rather areolate or verrucose, pale-greyish to yellow-grey thallus, $\mathrm{C}+$ orange-yellow, $\mathrm{K}+$ yellowish, UV+ orange (all reactions frequently very faint); black, lecideine apothecia, mostly $<0.8 \mathrm{~mm}$ diameter; a dark greenish-black to greenishbrown epithecium and outer excipulum edge; colourless hymenium; orange-brown hypothecium, intensifying orange in $\mathrm{K}$; asci with an amyloid tholus, having a convergent masse axiale with a rather rounded apex and a distinct amyloid zone above; simple paraphyses separating easily in $\mathrm{K}$; and simple ascospores, $10-17 \times 6-9 \mu \mathrm{m}$ (for further data, Purvis et al. 1992).

\section{Specimens examined}

Summit of Mt Wellington, 42 $54^{\prime} \mathrm{S}, 147^{\circ} 14^{\prime} \mathrm{E}, 1200 \mathrm{~m}, 9$ January 1989 , M. Allen (HO); Mt Ossa, $41^{\circ} 52^{\prime} \mathrm{S}, 146^{\circ} 02^{\prime} \mathrm{E}$, 1600 m, 14 March 1992, G. Kantvilas 116/92 (HO).

\section{Neofuscelia luteonotata (J. Stein.) Essl., Mycotaxon 7: 51(1978)}

This species is distinguished by the moderately to loosely adnate foliose thallus, the olive-brown to dark-brown upper surface, the pale-tan to pale-brown lower surface, the lack of isidia and the presence of medullary divaricatic and stenosporic acids (cortex $\mathrm{K}$-, $\mathrm{HNO}_{3}+$ dark blue-green, medulla $\mathrm{K}-, \mathrm{C}-, \mathrm{KC}-, \mathrm{P}-$ ). Its lobes are sublinear and irregularly branched, discrete to more often contiguous or subimbricate, and very rarely developing upright, subfruticose laciniae (for a full description, Esslinger 1977). Most of these morphological characters are also observed in $N$. scabrosina Elix and $N$. subimitatrix (Essl.) Essl., although the former has smaller spores $(6-9 \times 3.5-5.5 \mu \mathrm{m}$ as compared to $8-10 \times 5-7 \mu \mathrm{m}$ ) and the latter species tends to be more tightly adnate. These three species are distinguished most reliably by their chemistry as $N$. scabrosina contains constipatic acid, protoconstipatic acid and various scabrosin derivatives (medulla $\mathrm{K}-, \mathrm{C}-, \mathrm{KC}-, \mathrm{P}-$ ) while $N$. subimitatrix contains physodic acid (medulla KC+ rose-red).

Neofuscelia luteonotata is an occasional species on soil and rocks in southern Australia, previously reported from Victoria, South Australia and Western Australia. It is also known from southern Europe, Africa and New Zealand. $N$. luteonotata is apparently uncommon in Tasmania, where it was collected on vertical dolerite rocks in dry sclerophyll woodland.

\section{Specimen examined}

Gunners Quoin, summit area, $42^{\circ} 46^{\prime} \mathrm{S}, 147^{\circ} 20^{\prime} \mathrm{E}, 440 \mathrm{~m}$, 28 April 1992, G. Kantvilas \& J.A. Elix $186 / 92$ (CANB, $\mathrm{HO}$.

\section{Paraparmelia leucophaea Elix \& J. Johnst., Mycotaxon 32: 403 (1988)}

This species is characterised by the adnate to moderately adnate foliose thalli to $9 \mathrm{~cm}$ wide, the brown to dark-brown lower surface, the lack of soredia and isidia, and the presence of norstictic acid and salazinic acid in the medulla [medulla $\mathrm{K}+$ yellow then dark red, $\mathrm{P}+$ yellow-orange; containing atranorin, norstictic acid (minor), salazinic acid (major), connorstictic acid (trace), consalazinic acid (minor)]. The lobes are subirregularly to dichotomously branched, $1-3 \mathrm{~mm}$ wide but occasionally developing laciniae towards the thallus centre which are narrower $(0.5-1 \mathrm{~mm}$ wide), markedly imbricate and irregularly branched (full description, discussion and illustration, Elix \& Johnston 1988 ).

These characters are also found in Paraparmelia cerussata (Kurok.) Elix \& J. Johnst. but the latter is tightly adnate, has a paler lower surface and lacks salazinic acid. $P$. leucophaea is also known from southern New South Wales and eastern Victoria. This Australian endemic is apparently uncommon in Tasmania, where it was collected on \pm vertical dolerite rocks and soil banks in dry sclerophyll forest.

\section{Specimens examined}

Gunners Quoin, summit area, $42^{\circ} 46^{\prime} \mathrm{S}, 147^{\circ} 20^{\prime} \mathrm{E}, 440 \mathrm{~m}$, 28 April 1992, G. Kantvilas \& J.A. Elix 178/92 (CANB, HO); Risdon Brook below dam, 26 April 1969, G.C. Bratt (HO).

\section{Parmelia tarkinensis Elix \& Kantvilas, sp. nov. (PI. 2)}

Species cum thallo ut in Pamelia cunninghamii sed ab hac specie lobis sublinearibus, angustioribus et acidum protocetraricum et acidum echinocarpicum continente differt.

Type

Sumac Road, spur 2, south of Arthur River, $41^{\circ} 08^{\prime} S$, $145^{\circ} 02^{\prime} \mathrm{E}, 170 \mathrm{~m}$ elevation, on Tasmannia lanceolata in rainforest, 30 January 1992, G. Kantvilas 80/92, B. Fuhrer \& J. Jarman ( $\mathrm{HO}$ - holotype; $\mathrm{CBG}$ - isotype). 


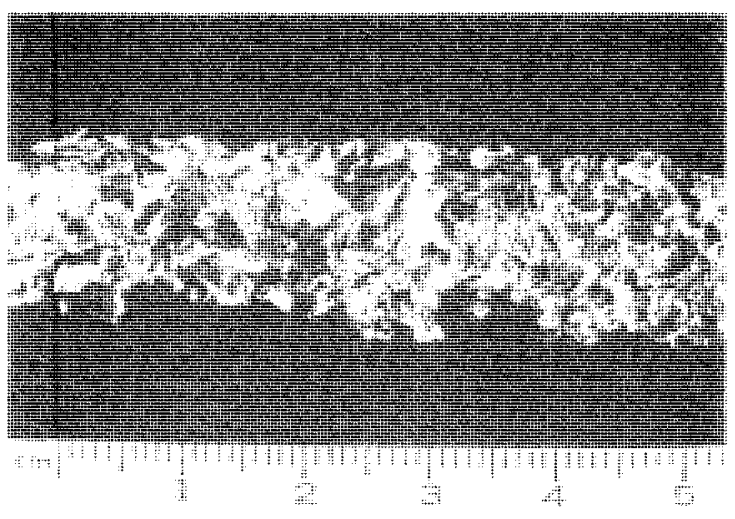

PLATE 2

Parmelia tarkinensis (holotype).

Thallus corticolous, firm, adnate, $2-8 \mathrm{~cm}$ diameter. Lobes sublinear, short, contiguous or ascending at the margins, 2-3 $\mathrm{mm}$ wide. Upper surface pale greenish grey to whitish grey, shiny but becoming dull and blackening with age, plane to rugose-foveolate with age, reticulately fissured only in the older parts, sorediate; soralia linear along the margins, orbicular when laminal, soredia farinose; pseudocyphellae effigurate, few, small, flecklike, mainly on the marginal lobes. Lower surface moderately to densely rhizinate, the rhizines simple to sqarrosely branched, 1-2 mm long. Pycnidia rare, marginal; conidia cylindrical, 5.5$7.0 \times 1 \mu \mathrm{m}$. Apothecia not seen.

\section{Chemistry}

Cortex $\mathrm{K}+$ yellow; medulla $\mathrm{K}+$ yellow, $\mathrm{C}-, \mathrm{P}+$ orange; containing atranorin, chloroatranorin, protocetraric acid (major), echinocarpic acid (major), conechinocarpic acid (minor).

Parmelia tarkinensis has affinities with $P$. cunninghamii but is distinguished by the narrower, sublinear lobes and medullary protocetraric and echinocarpic acids. P. cunninghamii develops similar soralia but has broader $(3-6 \mathrm{~mm}$ wide), irregular lobes with rotund apices and contains medullary salazinic and consalazinic acids. Chemically $P$. tarkinensis resembles $P$. protosulcata Hale (both contain protocetraric acid, but the latter lacks echinocarpic acid), but $P$. protosulcata has still narrower lobes (1-3 mm wide) which are linear-elongate and have truncate apices. In addition $P$. protosulcata has particularly coarse soredia which become partially corticate (sorediate-isidia), whereas $P$. tarkinensis and $P$. cunnighamii have fine, farinose soredia.

Parmelia tarkinensis is known only from northwestern Tasmania, where it is locally abundant in the extensive rainforesr stands south of the Arthur River. Although it has also been recorded as far south as the slopes of Mt Murchison (Anthony Road), these collections are very fragmentary and there the species appears to be very uncommon. In contrast, at the type locality it is probably the most common species of Parmelia present.

The new species appears to be confined to cool temperate rainforest below $600 \mathrm{~m}$ altitude, and occurs on canopy twigs. Associated lichens include Coccotrema cucurbitula, Menegazzia weindorferi, Parmelia protosulcata, P. tenuirima, Pertusaria truncata, Usnea oncodes and $U$. xanthopoga.

\section{Etymology}

The specific epithet is based on the word "Tarkine", a name which has been loosely ascribed to the forest and wilderness region in the Arthur and Pieman River catchments of Tasmania's northwest.

Specimens examined

Type locality, 24 May 1981, G. Kantvilas 294/81 (CANB, HO); Arthur-Pieman Protected Area, $35 \mathrm{~km}$ NNE of Savage River along the pipeline road, $41^{\circ} 18^{\prime} \mathrm{S}, 145^{\circ} 16^{\prime} \mathrm{E}$, 480 m, 8 December 1993, J.A. Elix 4014 \& G. Kantvilas (CANB); Anthony Road, 41 $49^{\prime} \mathrm{S}, 145^{\circ} 38^{\prime} \mathrm{E}, 480 \mathrm{~m}, 15$ November 1992, G. Kantvilas 520/92 (HO); same locality, G. Kantvilas 548/92, 206/91 (HO).

Parmotrema crinitum (Ach.) M. Choisy, Bull. Mens. Soc. Linn. Bot. Lyon 21:175 (1952) - Parmelia crinita Ach., Syn. Meth. Lich.: 196 (1814)

Parmotrema crivitum is characterised by an adnate thallus, lobes with ciliate margins, copious cylindrical isidia which are often ciliate, and the presence of the stictic acid complex in the medulla (for description and discussion, Elix 1994b). This species is apparently uncommon in Tasmania, where it has been recorded from the bark of Melaleuca ericifolia and Bursaria spinosa in a coastal swamp. In mainland Australia, this cosmopolitan species is common in coastal areas of Queensland, New South Wales and Victoria.

Specimens examined

Robbins Island Track, just south of Denium Hill, $25 \mathrm{~km}$ northwest of Smithton, $40^{\circ} 44^{\prime} \mathrm{S}, 144^{\circ} 53^{\prime} \mathrm{E}, 2 \mathrm{~m}, 10$ December 1993, J.A. Elix 40290 \& G. Kantvilas (CANB), G. Kantvilas 128/93 \& J.A. Elix (HO).

Physcia dubia (Hoffm.) Lett., Hedwigia 52: 254 (1912) - Lobaria dubia Hoffm., Deutsch. Fl. 156 (1796)

This species is characterised by the narrow lobes (rarely exceeding $1 \mathrm{~mm}$ ), the grey to grey-brown upper surface, which is usually distinctly darker at the lobe apices, and the marginal labriform soralia, mostly at the lobe tips. The lower surface is whitish and rhizinate, with a prosoplectenchymatous lower cortex, i.e. consisting of elongated hyphae in longitudinal section (for a full description, Moberg 1977 , Thomson 1963). This species possesses no medullary chemistry but the cortex is $\mathrm{K}+$ yellow (atranorin).

Physcia dubia is known from the Australian mainland (New South Wales and the Australian Capital Territory) and is a broadly distributed species also occurring in Eurasia, North America and East Africa. It is apparently rare in Tasmania, where it occurs on the Central Plateau on alpine and subalpine dolerite boulders manured by birds. Tasmanian specimens form rather irregular, loosely attached clumps, intermixed with Teloschistes velifer.

Specimens examined

Great Lake Plateau, $41^{\circ} 57^{\prime} \mathrm{S}, 146^{\circ} 40^{\prime} \mathrm{E}, 1000 \mathrm{~m}, 18$ January 1969, G.C. Bratt 69124 (HO); Central Plateau, Lake Augusta Dam, 41 $51^{\circ} \mathrm{S}, 146^{\circ} 35^{\prime} \mathrm{E}, 1140 \mathrm{~m}, 7$ December 1993, J.A. Elix 40068 \& G. Kantvilas (CANB), G. Kantvilas 181/93 \& J.A. Elix (HO).

Physcia dubia is superficially very similar to $P$. tribacia (Ach.) Nyl., to the extent that earlier authors, for example Thomson (1963), had suggested that the two taxa may not be distinct. However, P. tribacia clearly differs in the 
presence of a paraplectenchymatous lower cortex (seen as large isodiametric cells in longitudinal section) and also tends to have a shiny, unblackened upper surface, crenulate lobe tips and soralia which are initiated on the underside of the lobe tips (see also Purvis et al. 1992 for further data).

Previously recorded only tentatively from the Bass Strait islands, $P$. tribacia is here confirmed for the Tasmanian mainland. It occurs on lowland outcrops of dolerite, sandstone and granite, often in coastal areas, in dry sclerophyll forest and heathland.

Specimens examined

Mt Amos, Freycinet Peninsula, 42.09'S, 148 $17^{\circ} \mathrm{E}, 21$ August 1971, G.C. Bratt \& J.A. Cashin 71/1275 (HO); Cataract Gorge, 41⒉'S, $147^{\circ} 07^{\prime} \mathrm{E}, 15$ July 1984, G. Kantvilas 678/84 (HO); Bradys Point, 42032'S, $147^{\circ} 06^{\prime} \mathrm{E}$, 300 m, 2 August 1981, G. Kantvilas 454/81 (HO, BM); Old Beach Road opposite Cadburys, $42^{\circ} 47^{\prime} \mathrm{S}, 147^{\circ} 17^{\prime} \mathrm{E}, 5$ February 1984, G. Kantvilas \& P.W. James 296/84 (HO, BM).

\section{Protoblastenia calva (Dickson) Zahlbr., Catal. Lich. Univ. 7:1(1931) - Lichen calvus Dickson, Fasc. Plant. Cryptog. Brit. 2:18 (1789)}

Protoblastenia calva is characterised by an endolithic thallus, superficial, convex, orange, $\mathrm{K}+$ crimson apothecia to c. 1 $\mathrm{mm}$ diameter, ellipsoid spores, $8-15 \times 5-8 \mu \mathrm{m}$, and a colourless hypothecium (Poelt \& Vezda 1977). Only one other species of the genus, $P$. mpestris, is currently known from Tasmania; this species differs in having a superficial thallus and smaller apothecia.

Protoblastenia calva is widespread on limestone across the Northern Hemisphere. It appears to be rare in Tasmania, where it is known from a single collection from limestone outcrops in sedgeland.

Specimen examined

Vale of Belvoir, 41 $333^{\prime} \mathrm{S}, 145^{\circ} 53^{\prime} \mathrm{E}, 800 \mathrm{~m}, 21$ May 1993, G. Kantvilas 47/93 (HO).

\section{Xanthoparmelia jarmaniae Elix \& Kantvilas,} sp. nov. (PI. 3)

Species cum thallo ut in Xanthoparmelia mougeotina sed ab hac specie lobis laxe adnatis et acidum norsticticum, acidum salazinicum et acidum consalazinicum continente differt.

\section{Type}

Clifton Vale Road, $6 \mathrm{~km}$ west of Kempton, $42^{\circ} 32^{\prime} \mathrm{S}$, $147^{\circ} 08^{\prime} \mathrm{E}, 200 \mathrm{~m}$ elevation; on sandstone rocks in Eucalyptus woodland, 11 December 1993, J.A. Elix $40356 \&$ G. Kantvilas ( $\mathrm{HO}$ - holotype).

Thallus foliose to subcrustose, closely appressed, $1-3 \mathrm{~cm}$ diameter, \pm rosette forming. Lobes narrow, $0.5-$ $1.0(-1.5) \mathrm{mm}$ wide, stellate or rarely contiguous, not at all imbricate; apices markedly incised. Upper surface pale yellow-green but darkening to yellow-brown or black in the centre of the thallus, flat to slightly concave, shining at apices, dull and irregularly cracked near centre of thallus, becoming crustose-areolate with age, isidiate; isidia small $(0.1-0.2 \mathrm{~mm})$, simple, cylindrical at first but moderately branched, brown-tipped, sparse to moderately dense, apices

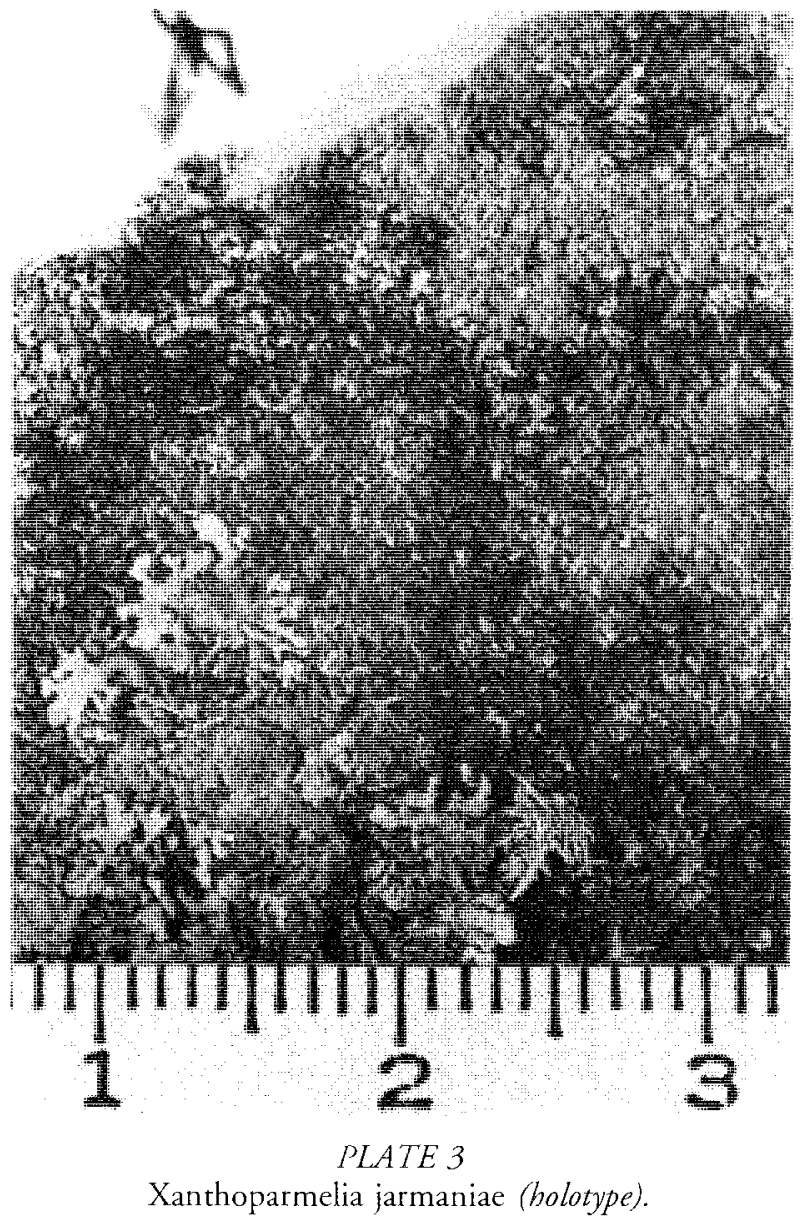

syncorticate; lacking maculae and soredia; medulla white. Lower surface black to dark brown, smooth, shining, sparsely rhizinate, rhizines simple, black. Apothecia and pycnidia not seen.

Chemistry

Cortex $\mathrm{K}+$ yellow; medulla $\mathrm{K}+$ yellow then red, C-, KC-, P+ yellow-orange; containing usnic acid, norstictic acid (major), salazinic acid (major), consalazinic acid (minor).

In the Australian flora, Xanthoparmelia jarmaniae most closely resembles $X$. mougreotina (Nyl.) D. Gall., since both species have small foliose to subcrustose thalli, cylindrical isidia with syncorticate apices and a black lower surface. However, the lobes and thalli of $X$. jarmaniae are not as tightly adnate as those of $X$. mougeotina. Furthermore, the two species differ chemically with $X$. mougeotina containing the stictic acid chemosyndrome (medulla $K+$ yellow) rather than norstictic and salazinic acids. On other continents, only X. minuta Hale from South America (Hale 1986) approaches $X$. jarmaniae. The former differs in having subglobose, unbranched isidia and containing gyrophoric acid and protoconstipatic acid in addition to the substances observed in $X$. jarmaniae.

Xanthoparmelia jarmaniae is hitherto known only from the type locality, a low rainfall area (c. 500-600 mm per annum) with extensive dry sandstone bluffs and dry sclerophyll forest. This region is one of exceptional lichenological interest, supporting several species which are unknown elsewhere in Tasmania, for example Pyxine nubila, Melanelia piliferella, $X$. exillima and X. mbrireagens. 
Etymology

This species is named in honour of our friend and colleague, Dr S J. Jarman, in recognition of her contribution to the knowledge of Tasmanian vegetation.

\section{REFERENCES}

ArCH :R, A.W., 1992: Cladoniaceae. Flora of Australia 54: 107152.

Elix, J.A., 1994a: Hypotrachyna. Flord of Australia 55: 49-59.

Eulx, J.A., 1994b: Parmotrema. Flora of Australia 55: 140-162.

Er.IX, J.A. \& Jenkins, G.A. (1989). New species and new records of Hypogymnia (Lichenized Ascomycotina). Mycotaxon 35: 469-476.

Elix, J.A. \& JoHnston, J., 1988: New species in the lichen genus Paraparmelia (Ascomycotina) from the Southern Hemisphere. Mycotaxon 32: 399-414.

ESSINNGER, T.L., 1977: A chemosystematic revision of the brown Parmeliae. J. Hattori Bot. Lab. 42: 1-211.

Filson, R.B., 1992: Candelariaceae. Flora of Australia 54: 97101.

GALLOWAY, D.J., 1985: FLORA OFNEW ZEALAND. LICHENS. Government Printer, Wellington.
Hertel, H., 1985: Lecideaceae Exsiccatae. Fasc. 8: 150.

Kantvilas, G., 1988: Tasmanian rainforest lichen communities: a preliminary classification. Phytocoenologia 16:391-428.

KantviLAS, G., 1994: A revised checklist of the Tasmanian lichen flora. Muelleria 8: 155-175.

KAN'VILAS, G. \& JARMAN, S.J., 1988: Lichens of buttongrass (Gymnoschoenus) moorland in Tasmania. Pap. Proc. R. Soc. Tasm. 122: 1-17.

Moberci, R., 1977: The lichen genus Physcia and allied genera in Fennoscandia. Acta Univ. Upsal. 22: 1-108.

PoElT, J. \& VLZDA, A., 1977: BESTIMMUNGSSCHLÜSSEL EUROPAÏSCHER FLECHTEN. ERGÄNZUNGSHEFT 1. J. Cramer, Vaduz.

Purvis, O.W., Coppins, B.J., Hawksworth, D.L., James, P.W. \& MOORE, D.M., 1992: THE LICHEN FIORA OF GREAT BRITAIN AND IRELAND. Natural History Museum Publications, London.

SCHEnEcGar, C., 1993: A revision of European saxicolous species of the genus Buellia De Not. and formerly included genera. Lichenologist 25: 315-364.

Thomson, J.W., 1963: The lichen genus Physcia in North Anerica. Beih. Nova Hedwigia 7: 1-172.

WIRTH, V., 1987: DIE FLECHTEN BADENWÜRTTEMBERGS. Eugen Ulmer, Stuttgart.

(accepted 26 April 1995) 